\title{
Pelatihan Optimalisai Tumbuh Kembang Anak pada Orangtua Anak Usia Dini ${ }^{1}$
}

\author{
Radhiya Bustan ${ }^{1}$, Nurfadilah ${ }^{2}$, Nila Fitria ${ }^{3}$ \\ ${ }^{1}$ Program Studi Psikologi, ${ }^{2,3}$ Program Studi Pendidikan Anak Usia Dini, \\ Fakultas Psikologi dan Pendidikan, Universitas Al-Azhar Indonesia \\ Komplek Masjid Agung Al Azhar, Jl.Sisingamangaraja, Jakarta 12110 \\ Penulis untuk Korespondensi/E-mail: radhiya_bustan@uai.ac.id
}

\begin{abstract}
Abstrak - Mendidik dan mengasuh seorang anak tentunya membutuhkan pengetahuan akan tumbuh kembang anak. Adapun aspek perkembangan anak usia dini meliputi tiga aspek, yaitu aspek fisik, kognitif dan psikososial (Papalia \& Olds, 1995). Anak usia dini adalah anak-anak yang berada pada usia 0-8 tahun. Pendidikan keorangtuaan menjadi penting bagi orangtua supaya orangtua dapat memaksimalkan perkembangan semua potensi anak, baik fisik, kognitif, maupun psikososial anak. Berdasarkan hasil penelitian pendahuluan, diperoleh hasil bahwa sebagian besar orangtua berharap memperoleh pengetahuan terkait pendidikan keorangtuaan yang dilaksanakan dalam bentuk pelatihan karena mereka masih sangat minim memperoleh informasi yang terkait dengan tatanan praktisnya. Untuk itu, kegiatan pengabdian masyarakat ini menggunakan intervensi berupa pelatihan dengan tujuan untuk mengoptimalkan tumbuh kembang anak melalui Pelatihan pada Orangtua Anak Usia Dini. Setelah melakukan pelatihan, diperoleh hasil dari kuesioner menunjukkan bahwa (1) $90 \%$ peserta pelatihan merasa bahwa materi yang dibawakan pembicara sesuai dengan kebutuhan serta materinya mudah untuk dipahami, (2) $80 \%$ peserta pelatihan berusaha mempraktekkannya dalam mengajar di lembaga PAUD atau mendidik anaknya, (3) $80 \%$ peserta pelatihan menjadi bersemangat menjalani hari-hari sebagai orangtua setelah melakukan kegiatan pelatihan ini. Dengan demikian dapat disimpulkan bahwa intervensi yang dilakukan tepat guna dan sesuai dengan hasil penelitian terdahulu meskipun topik yang diberikan belum menyeluruh. Oleh karena itu, perlu ada pelatihan untuk pemberian materi dasar lanjutan tentang perkembangan anak, yang mencakup aspek fisik, seni, dan moral agama. Sebagai saran selanjutnya, pelatihan yang sifatnya aplikatif terhadap permasalahan tertentu akan efektif dilaksanakan jika peserta telah memahami pengetahuan dasar secara menyeluruh. Materi tersebut sebaiknya diidentfikasi pada saat pelatihan dasar lanjutan berakhir agar tepat guna.
\end{abstract}

\section{Kata Kunci - Mengasuh anak, latihan, Anak Usia Dini}

Abstract - Parent needs to know about child care education to help children grow and develop their potential according their age and capability, especially in early years. Parents have to stimulate the three areas of child development, physics, cognitive, and psychosocial (Papalia \& Olds, 1995). According to our preliminary research, parents needs practical knowledge that can help them in optimizing their children at their best. The research was followed by an intervention program in a form of training. The training was begun with providing general topic, such as parent's role in educating the children, and then continued with a specific topic such as child's psychosocial development and child's cognitive development. Effectivity of training was measured trough questioner. The result are (1) $90 \%$ of participants stated that the materials that were given to them is easily understood and suitable for their needs, (2) $80 \%$ of participants have tried to practiced with the children in their institution and their home, (3)

\footnotetext{
${ }^{1}$ Paper ini telah diseminarkan di seminar internasional “ International Conference of Early Childhood Education 2015 (ICECE ) Universitas Padang pada tanggal 20-21 September 2015
} 
80\% of participants become highly motivated to run their role as a parent and educator for the children. It can be concluded that the intervention has been appropriate and in accordance with the results preliminary research although a given topic has not been all thorough. Therefore, there needs to do advanced training of basic materials on child development, which includes the physical, art, and moral religion topics. For further advice, the training that will be conducted later are more practical to specific issues and the material should be identified during the basic training in order to get the best benefit to the participants.

Keywords - parenting, training, early childhood

\section{PENDAHULUAN}

\section{Latar Belakang}

Dendidikan Anak Usia Dini di dalam UU No. 20 Tahun 2003 adalah upaya pembinaan sejak lahir sampai dengan usia 6 tahun dan dilakukan dengan memberikan rangsangan pendidikan, ini sangat membantu perkembangan dan pertumbuhan jasmani dan rohani anak supaya mempunyai kesiapan untuk memasuki pendidikan lebih lanjut. Untuk mendidik dan mengasuh seorang anak tentunya dibutuhkan pengetahuan akan tumbuh kembang anak. Adapun aspek perkembangan anak usia dini meliputi tiga aspek, yaitu aspek fisik, kognitif dan psikososial (Papalia \& Olds, 1995).

Salah satu aspek perkembangan yang berkembangan dengan pesat pada masa anak usia dini adalah aspek kognitif. Anak usia dini adalah anak-anak yang berada pada usia 0-8 tahun. Pada masa itu disebut juga masa keemasan (golden aged). Dimana hampir $80 \%$ perkembangan kognitif berkembang pada masa ini. Piaget berpendapat bahwa kita membangun kemampuan kognitif kita melalui tindakan yang termotivasi dengan sendirinya terhadap lingkungan. Piaget (Henniger, 2013) menekankan bahwa anak-anak secara aktif membangun dunia kognitif mereka sendiri, informasi dari lingkungan tidak begitu saja dituangkan ke dalam pikiran-pikiran mereka.

Aspek lain yang juga sangat perlu diperhatikan dalam perkembangan anak adalah aspek psikososial. Perkembangan aspek psikososial ini termasuk pembentukan karakter anak. Pendidikan karakter merupakan pembentukan perilaku, pola pikir dan emosi positif. Semua hal ini sangat terkait dengan komunikasi antara orangtua dan anak yang dapat dilakukan secara optimal apabila orangtua memahami aspekaspek perkembangan anak.

Untuk itu perlu pendidikan dan pengasuhan yang tepat terhadap tumbuh kembang anak usia dini ini. Dimana orangtua memegang peran yang sangat penting dalam pendidikan dan pengasuhan anak usia dini. Namun, untuk menjadi orangtua tidak ada sekolahnya sehingga banyak orangtua yang memfasilitasi potensi kognitif anak dengan memasukkan ke tempat-tempat bimbingan belajar dengan harapan mereka bisa calistung dengan cepat. Selain itu, orangtua yang cenderung sibuk bekerja juga kurang memberikan perhatian terhadap perkembangan psikososial anak. Sehingga pada masa beranjak dewasa, anak tidak mampu mengadopsi nilai-nilai positif yang harus ia kembangkan sebagai karakter yang kuat. Banyak yang akhirnya terlibat dengan berbagai tindakan melanggar hukum, kekerasan, narkoba, dan lain sebagainya.

Pendidikan keorangtuaan menjadi penting bagi orangtua supaya orangtua dapat memaksimalkan perkembangan semua potensi anak, baik fisik, kognitif, maupun psikososial anak. Selaras dengan prinsip pembelajaran anak usia yaitu belajar melalui bermain menjadikan aktivitas belajar menjadi kegiatan yang menyenangkan. Bukan hanya untuk mengoptimalkan kemampuan yang dimiliki anak tetapi juga untuk mempertajam indra yang dimiliki oleh anak.

Lev Vygotsky (Henniger, 2013) berpendapat bahwa perkembangan kognitif dan Bahasa anak tidak berkembang di dalm ruang yang hampa melainkan perlunya peran orang dewasa dan anak-anak disekitarnya yang memudahkan perkembangan anak. Selain itu, perkembangan psikososial anak akan terbentuk dengan 
komunikasi efektif antara orangtua dan anak sebagai role model yang positif.

Untuk itu, kegiatan pengabdian masyarakat ini kami lakukan dalam bentuk pelatihan yang merujuk pada penelitian terdahulu yang sudah kami lakukan, yaitu penelitin "Harapan Orangtua terhadap Pendidikan Keorangtuaan" dimana hasil penelitian menyatakan $80 \%$ orangtua menghendaki pelatihan dengan materi perkembangan anak. Sehubungan dengan hal yang dikemukakan di atas maka kegiatan pengabdian masyarakat ini mengangkat tema "Pelatihan Optimalisasi Tumbuh Kembang Anak pada Orangtua Anak Usia Dini di PAUD Kemuning, Kampung Bulak - Larangan Ciledug - Tangerang".

\section{Perumusan Masalah}

Berdasarkan hasil penelitian pendahuluan (preliminary research), diperoleh hasil bahwa sebagian besar orangtua berharap memperoleh pengetahuan terkait pendidikan keorangtuaan yang dilaksanakan dalam bentuk pelatihan karena mereka masih sangat minim memperoleh informasi tersebut terutama yang terkait dengan tatanan praktisnya. Untuk itu, perumusan masalah dalam kegiatan pengabdian masyarakat ini adalah:

Apakah Kegiatan Pelatihan Optimalisasi Tumbuh Kembang Anak pada Orangtua Anak Usia Dini di Kampung Bulak - Larangan dapat efektif sebagai sarana pemberian pendidikan keorangtuaan?

\section{Tujuan}

Tujuan kegiatan ini adalah untuk mengoptimalkan tumbuh kembang anak melalui Pelatihan Orangtua Anak Usia Dini bertujuan meningkatkan kemampuan orangtua dalam memberikan pembelajaran kepada anak usia dini sesuai dengan perkembangannya.

\section{Manfaat}

Adapun manfaat kegiatan pengabdian masyarakat ini antara lain:

1. Orangtua - Orangtua dapat menambah
pengetahuan tentang pembelajaran
yang menyenangkan di rumah

- Orangtua dapat mempraktekkan langsung pengetahuan yang diperoleh setelah mengikuti pelatihan

2. Mahasiswa
- Belajar menerapkan konteks teoritis dan fakta ke dalam praktek (theory in to action)

- Melatih kepekaan terhadap masalahmasalah yang terjadi di dalam masyarakat

3. Dosen

- Mewujudkan salah satu tridharma perguruan tinggi, yaitu pengabdian masyarakat

- Mengasah empati dan kepekaan terhadap masalah yang terjadi di masyarakat

4. Fakultas Psikologi dan Pendidikan

- Memperluas akses jaringan di dalam masyarakat

- Sarana untuk mempromosikan Fakultas Psikologi dan Pendidikan

\section{Ruang Lingkup}

Adapun bentuk kegiatan adalah pelatihan parenting, dengan fokus pada perkembangan aspek psikososial dalam bentuk pendidikan karakter serta pelatihan terkait perkembangan kognitif anak melalui Pelatihan Orangtua Anak Usia Dini. Pelaksanaan pelatihan akan dibagi menjadi beberapa sesi pertemuan agar dapat memberikan waktu bagi para peserta untuk mengaplikasikan materi yang diperoleh dan dievaluasi pada pertemuan berikutnya.

\section{TINJAUAN PUSTAKA}

\section{Aspek Perkembangan Anak}

Banyak peneliti berpendapat bahwa stimulasi sejak dini sangatlah penting karena pada waktu manusia lahir kelengkapan organisasi otak memuat 100-200 milyar sel otak siap dikembangkan serta diaktualisasikan untuk mencapai tingkat perkembangan potensi tertinggi (Clark dalam Semiawan, 2004: 27). Perkembangan anak pada usia dini meliputi tiga aspek, yaitu aspek fisik, kognitif dan psikososial (Papalia \& Olds, 1995). Program pendidikan usia dini yang ada di Indonesia antara lain adalah Tempat Penitipan Anak,; Kelompok Bermain, dan Taman Kanak-kanak (Patmonodewo, 2000). Brooks (1991) berpendapat bahwa orangtualah yang berperan besar dalam megoptimalkan pertumbuhan dan perkembangan anak di seluruh aspek perkembangan, baik aspek fisik, kognitif maupun psikososial. 
Optimalisasi tumbuh kembang AUD sangat penting karena membantu meletakkan dasar ke arah perkembangan sikap, perilaku, pengetahuan, keterampilan dan daya cipta, yang ia perlukan untuk menyesuaikan diri dengan lingkungan dan untuk pertumbuhan serta perkembangan selanjutnya. Dengan demikian anak diharapkan memiliki kesiapan untuk sekolah.

Kesiapan sekolah adalah syarat mutlak pemrolehan keterampilan, pengetahuan, sikap, motivasi dan tingkah laku lain yang memungkinkan peserta didik untuk meraih hasil yang maksimal dari instruksi yang diberikan di sekolah (Anastasi, 1997). Ausubel (dalam Gredler, 1992) menambahkan bahwa kesiapan sekolah membuat anak belajar dengan mudah tanpa adanya tekanan emosional dan membuatnya termotivasi untuk berusaha mendapatkan hasil dari pembelajaran (Gredler, 1992). Adapun indikasi anak yang memiliki kesiapan sekolah adalah (1) menunjukkan adanya kesejahteraan fisik (physical wellbeing), (2) kematangan emosi, (3) kepercayaan sosial, (4) kemampuan penggunaan bahasa dan (5) memiliki pengetahuan umum.

Kegiatan pengabdian masyarakat ini berfokus pada perkembangan aspek psikososial dan aspek kognitif pada anak usia dini karena keterbatasan waktu. Untuk perkembangan fisik anak usia dini akan dilanjutkan pada kegiatan pengabdian masyarakat berikutnya.

\section{Perkembangan Fisik (Motorik)}

Perkembangan fisik adalah perkembangan yang berhubungan dengan perolehan aneka ragam keterampilan fisik (motorik). Hal itu mencakup pertumbuhan otak dan tubuh, kemampuan sensoris, keterampilan motorik, dan kesehatan.

\section{Perkembangan Psikososial}

Perkembangan aspek psikososial menyangkut keterampilan emosional dan sosial. Perkembangan sosial berkaitan dengan bagaimana individu berhubungan dengan orang lain sedangkan perkembangan emosi berhubungan dengan kemampuan untuk mengenali perasaan diri sendiri dan orang lain. Rey dan Putnam (2002) berpendapat bahwa keterampilan sosial merupakan strategi perilaku yang spesifik, yang memungkinkan seseorang untuk memulai dan menjalin interaksi sosial yang positif dengan orang lain, mengembangkan persahabatan dan jaringan dukungan sosial, serta menyesuaikan diri dengan lingkungan sosial secara efektif. Menurut Combs dan Slaby (dalam Cartledge dan Milburn, 1995), keterampilan sosial adalah kemampuan untuk berinteraksi dengan orang lain dengan cara-cara tertentu, yang dapat diterima atau dihargai secara sosial dan membawa manfaat, baik bagi diri sendiri, orang lain, maupun keduanya.

Perkembangan psikososial anak juga terkait dengan pembentukan karakter. Karakter tidak bisa diwariskan, karakter tidak bisa dibeli dan karakter tidak bisa ditukar. Menurut Timothy, karakter harus dibangun dan dikembangkan secara sadar hari demi hari dengan melalui suatu proses yang tidak instan. Karakter bukanlah sesuatu bawaan sejak lahir yang tidak dapat diubah lagi seperti sidik jari. Untuk itu, perlu pengetahuan orangtua dalam membentuk karakter positif pada anak.

\section{Perkembangan Kognitif}

Piaget (Morrison,2012) teori perkembangan kognitif menjelaskan cara orang berpikir, memahami, dan belajar. Kecerdasan adalah proses kognitif atau mental yang digunakan anak untuk memperoleh pengetahuan. Keterlibatan aktif adalah dasar teori Piaget yang mengatakan bahwa anak mengembangkan kecerdasan lewat pengalaman/praktik langsung di lingkungan fisik. Sehingga Piaget membaginya dalam empat tahap perkembangan kognitif , yaitu :

1. Sensorimotor: dari lahir sampai dengan dua tahun, dimana anak menggunakan indera dan gerak reflek untuk menyusun pengetahuan tentang dunianya.

2. Pra operasional: mulai usia dua tahuntujuh tahun, dimana anak menggunakan symbol seperti kata-kata atau gambaran dalam pikiran untuk menyelesaikan masalah dan memikirkan tentang bendabenda dan orang-orang yang tidak berada di dekatnya. Menggunakan system simbol (Bahasa)

3. Operasional Konkret : tujuh tahun duabelas tahun, dimana baik prose fisik maupun mental dapat dibalik dan dibatalkan oleh yang lainnya

4. Operasional Formal : dua belas tahunempat belas tahun, dimana anak mulai menghadapi masalah-masalah verbal dan 
hipotesis yang semakin kompleks dan kurang begantung pada benda konkrit

Pelatihan keorangtuaan menjadi hal yang penting, dimana orangtua harus mengetahui perkembangan anak. Menurut Maria Montessori (Morrison, 2012) tiga area dasar keterlibatan anak, yaitu :

1. Kehidupan praktis atau pendidikan motorik

2. Materi sensorik untuk pelatihan indera

3. Materi akademik untuk menulis, membaca dan matematika

Tiga area ini sangat berpengaruh besar dalam pendidikan anak usia dini.

Materi akademik dalam pengembangan kognitif menurut Montesori mencakup menulis, membaca dan matematika. Dalam praktik metode Montessori ada beberapa hal yang diperhatikan :

1. Membaca, menulis, dan latihan- latihan awal materi sensoris

Memanfaatkan media Montessori seperti huruf-huruf kertas sandpaper, anak belajar mengenali huruf -huruf dengan cara melihat dan menyentuh, disamping mendengarkan setiap huruf yang diucapkan. Kartu-kartu perintah, gambar dan bunyinya, huruf yang berpindah.

2. Latihan-latihan aritmatika

Memanfaatkan media Montessori seperti angka-angka kertas sandpaper, balok-nalok angka, menulis angka-angka, dan latihan mengukur.

Media Montessori merupakan media yang memungkinkan anak-anak akrab dengan angkaangka dan huruf-huruf pada tahun-tahun awal saat mereka sangat responsive terhadap jenis pengalaman ini. Orangtua anak usia dini dapat melakukan kegiatan ini di rumah. Tanpa harus memaksakan kemampuan kognitif anak dengan cara yang tidak ramah dengan anak.
Pada kegiatan pelatihan ini, kami juga menambahkan materi terkait pendidikan karakter pada AUD yang juga akan sangat menunjang perkembangan kognitif AUD. Teori ini di kemukakan oleh Charles Spearman (1994) yang berpendapat kognitif adalah kemampuan umum yang diberi kode "g"(general factors) dan kemampuan khusus ang diberi kode "s"(specific Factors). Setiap individu memiliki kemampuan ini yang keduanya menentukan penampilan atau perilaku mentalnya. Lain halnya dengan Teori Primary Mental Abilities yang merupakan salah satu tes intelegensi dikemukakan dengan Thurstone yang berpendapat kognitif adalah penjelmaan dari kemampuan primer, yaitu kemampuan (Veenman, tanpa tahun:1):

a. Berbahasa (Vocal Comprehension)

b. Mengingat (Memory)

c. Nalar atau berfikir logis (Reasoning)

d. Pemahaman ruang (Spatial Factor)

e. Bilangan (Numerical Ability)

f. Menggunakan kata-kata (Word Fluency)

g. Mengamati dengan cepat dan cermat (Perceptual Speed)

Kemampuan primer ini akan mewakili pada perkembangan kognitif anak. Penting bagi orangtua memberikan stimulasi, pendidikan, dan pengasuhan untuk mengoptimalkan perkembangan kognitif anak.

\section{METODE INTERVENSI (PELATIHAN)}

Intervensi adalah suatu tindakan yang menghasilkan perubahan atau usaha untuk merubah seseorang, populasi, atau organisasi yang menjadi subyek evaluasi (Øvretveit,1998). Adapun tujuan dari intervensi adalah untuk menghasilkan suatu perubahan serta membuat perubahan dalam hidup seseorang (Øvretveit,1998). 
Bentuk intervensi yang dilakukan adalah pelatihan yang merupakan tahap awal dari implementasi hasil penelitian. Pelatihan dilakukan di kediaman salah satu pengurus RT dalam situasi yang tidak formal, menyenangkan, dan melibatkan peserta secara aktif.

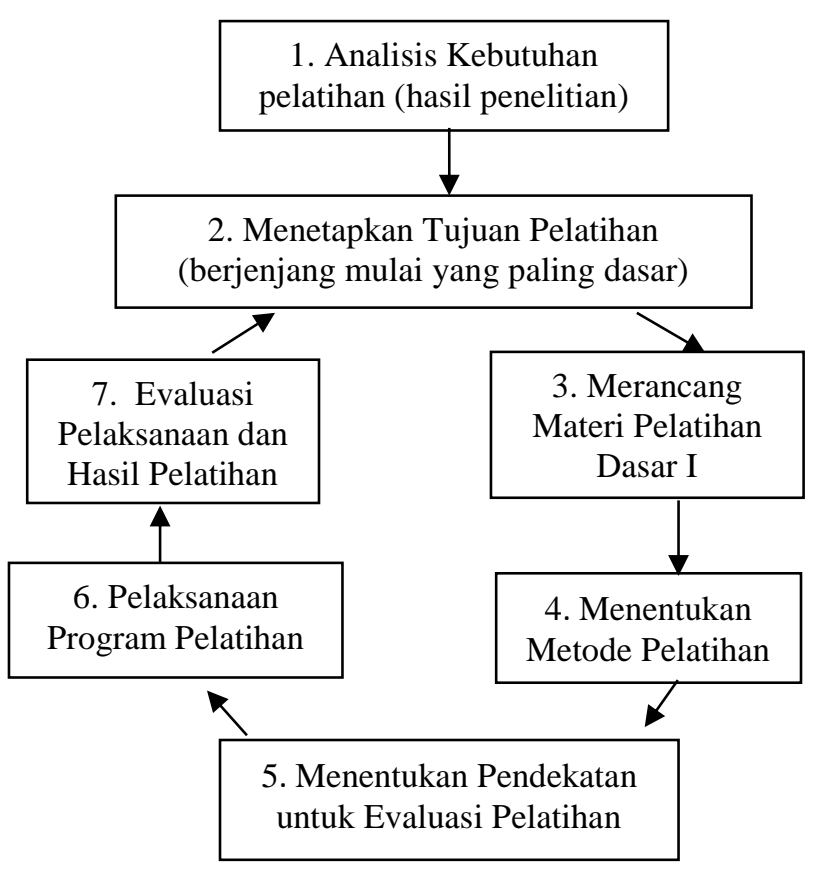

Gambar 1. Desain Pelatihan

\section{SOSIALISASI DAN PROFIL RESPONDEN}

\section{Sasaran Khalayak}

Pelatihan ini akan diberikan pada 40 orangtua yang mempunyai anak yang bersekolah di PAUD Kemuning, Kampung Gaga, Ciledug Tangerang. Orangtua yang dimaksud mempunyai kriteria sebagai berikut:

1. Bekerja sebagai: supir, pedagang asongan, pemulung, tukang ojek, satpam, kuli bangunan, penjual gado-gado, tukang cuci, dan lain-lain.

2. Penghasilan per-bulan di bawah Upah Minimum Regional (UMR) untuk DKI Jakarta tahun 2014 yaitu di bawah Rp. 2.441.000,- (http://allows.wordpress.com).

3. Tinggal di rumah dengan kondisi sangat tidak layak.

\section{Kondisi Subjek Dampingan Saat Ini}

Di Indonesia, pendidikan keorangtuaan umumnya dilakukan di lembaga-lembaga PAUD atau melalui Posyandu. Namun, belum semua orangtua dapat mengaksesnya terutama masyarakat golongan ekonomi lemah, salah satunya orangtua siswa di PAUD Kemuning Ciledug - Tangerang. PAUD ini hanya bertempat di garasi rumah salah seorang warga, dengan biaya yang sangat minim karena disesuaikan dengan kemampuan orangtua murid yang sangat terbatas secara financial. Oleh karena itu, dosen beserta mahasiswa/i Fakultas Psikologi dan Pendidikan memandang perlu untuk berperan serta dalam menyelenggarakan pendidikan keorangtuaan pada orangtua dari kalangan ekonomi lemah agar dapat meningkatkan pemahaman mereka dalam mengembangkan kemampuan psikososial dan kognitif anak mereka.

\section{Waktu dan Tempat}

Kegiatan ini secara keseluruhan dilakukan selama 6 bulan, dalam rentang bulan November - Maret 2015. Pelatihan ini akan dilaksanakan di PAUD Kemuning yang beralamatkan Jalan H.Marzuki Kampung Pulo RW 015 Kelurahan Gaga Kecamatan Larngan Kota TangerangBanten. PAUD Kemuning ini memiliki siswa sebanyak 50 siswa dengan latar belakang dari ekonomi lemah.

\section{LANGKAH-LANGKAH KEGIATAN}

\section{Persiapan}

Kegiatan ini dimulai dengan mempersiapkan materi-materi yang berkaitan dengan pelatihan parenting yang akan diberikan. Metode dan materi yang diberikan merujuk kepada penelitian terdahulu yang sudah kami lakukan, yaitu penelitian "Harapan Orangtua terhadap Pendidikan Keorangtuaan". Fokus pelatihan ini adalah memberikan pemahaman kepada orangtua dalam mengembangkan kemampuan psikososial dan kognitif anak usia dini.

\section{Pelaksanaan}

Pelaksanaan pelatihan ini pada bulan Januari Maret 2015 di PAUD Kemuning, Kampung Pulo - Tangerang. Media yang digunakan adalah papan tulis, spidol, LCD Proyektor, In focus sebagai sarana ketika memberikan materi pelatihan. Selain itu peserta juga akan diberikan buku yang berisi materi yang akan diberikan, buku tulis untuk mencatat, serta alat-alat tulis lainnya.

Pelatihan pertama dilakukan pada hari Sabtu, tanggal 10 Januari 2015 dan dihadiri oleh 40 
orang peserta. Materi yang diberikan adalah tentang "Peran Orangtua dalam Mencerdaskan Anak", dengan Nurfadilah, M. Psi sebagai pemateri. PAda sesi Tanya jawab, permasalahan yang diajukan oleh peserta terkait dengan permasalahan perkembangan anak dan kemampuan akademik anak, seperti yang terkait dengan temperamen anak, kegemaran anak menonton kartun dan kemampuan membaca, menulis dan berhitung.

Pelatihan kedua dilakukan pada hari Jumat, 7 Februari 2015 yang dihadiri oleh 34 orang peserta. Pemateri pertama adalah Radhiya Bustan, M. Soc, Sc dengan materi Perkembangan Psikososial pada Anak Usia Dini kemudian dilanjutkan dengan pemateri kedua oleh Nila Fitria, M.Pd dengan materi Pengembangan Kemampuan Kognitif Anak Usia Dini.

\section{Pelaporan}

Langkah terakhir yang dilakukan adalah membuat laporan dari keseluruhan kegiatan pengabdian masyarakat "Pelatihan Optimalisasi Tumbuh Kembang Anak pada Orangtua Anak Usia Dini" yang telah dilakukan. Disamping itu, akan dilakukan juga evaluasi terhadap kegiatan dengan memberikan pertanyaan mengenai tanggapan peserta pelatihan mengenai pelatihan yang telah diberikan tersebut.

\section{Media}

Media yang digunakan adalah LCD Proyektor, laptop, papan tulis, spidol sebagai media untuk presentasi materi. Selain itu juga dibutuhkan bahan-bahan untuk pelatihan. Dilengkapi dengan microphone dan media lainnya yang diperlukan saat pelatihan dan proses tanya jawab. Keseluruhan perlengkapan tersebut difasilitasi oleh PAUD Kemuning bekerjasama dengan ketua RT Kampung Pulo.

\section{HASIL DAN PEMBAHASAN}

\section{Pelatihan Sesi Pertama}

Kegiatan "Pelatihan Optimalisasi Tumbuh Kembang Anak pada Orangtua Anak Usia Dini" ini dibagi menjadi tiga sesi. Sesi pertama diawali dengan seminar mengenai "Peran Orangtua dalam Mencerdaskan Anak", pada hari Sabtu 10 Januari 2015. Pemateri pada sesi pertama ini adalah salah seorang tim kegiatan pengabdian masyarakat yaitu Nurfadilah, M. Psi. Seminar ini bertujuan untuk memetakan materi yang sesuai dengan kebutuhan orangtua siswa PAUD Kemuning. Materi ini adalah pengantar untuk kegiatan pelatihan yang akan dipraktekkan pada pertemuan sesi ketiga. Setelah seminar dilaksanakan, tim melakukan survey mengenai kebutuhan orangtua peserta seminar terhadap materi pendidikan keorangtuaan. Hasil tersebut akan ditindaklanjuti dengan pelatihan pada sesi berikutnya sesuai dengan kebutuhan orangtua yang hadir pada seminar tersebut. Orangtua yang hadir pada seminar pertama dengan tema "Peran Orangtua dalam Mencerdaskan Anak" berjumlah 40 orang. Hasil survey menunjukkan bahwa orangtua sangat membutuhkan materi terkait bagaimana memahami anak mereka dengan mengamati anak lain yang sebaya (Hasil Terlampir). Dengan kata lain, mereka sangat memerlukan materi terkait dengan perkembangan Anak Usia Dini dan bagaimana cara mengoptimalkannya. Hasil lain terkait kegiatan yang akan dilakukan selanjutnya adalah mereka mengharapkan agar dilakukan dalam bentuk praktek, dilaksanakan pada hari kerja ketika anak-anak sedang sekolah, dengan durasi 2 jam.

\section{Pelatihan Sesi Kedua}

Berdasarkan hasil kegiatan sesi pertama, maka kegiatan sesi kedua kami isi dengan materi terkait pengembangan kemampuan psikosial anak usia dini termasuk pengembangan karakter yang diintegrasikan dengan pendekatan Islam. Pemateri pada sesi kedua ini adalah Radhiya Bustan, M. Soc, Sc. Adapun tema yang diangkat pada sesi ini adalah "Perkembangan Psikososial pada Anak Usia Dini" (Materi terlampir). Pertemuan ini dilaksanakan pada tanggal 7 Februari 2015 dengan jumlah peserta 34 orang peserta. Jika dibandingkan dengan pertemuan pertama, jumlah peserta pada pertemuan kedua ini lebih sedikit karena dilaksanakan pada hari kerja sehingga ada yang berhalangan hadir. Pada materi ini, pembicara menjelaskan perkembangan psikososial anak usia dini secara umum dan kemudian mengajak orangtua untuk mengobservasi perilaku anak-anak mereka dan memahami apa faktor yang menyebabkan timbulnya perilaku tersebut. Melalui proses pengamatan dan evaluasi tersebut, orangtua dapat membentuk pola baru dalam mengembangkan kemampuan anak untuk 
mengelola emosi dan pikirannya sehingga terbentuk perilaku yang positif.

Membangun kedekatan emosional dengan anak dilakukan melalui komunikasi efektif, dengan cara antara lain sebagai berikut:

1. Menggunakan kata "minta" saat kita meminta anak untuk melakukan sesuatu

2. Menatap mata anak ketika kita berkomunikasi dengannya

3. Menyertai komunikasi dengan kontak fisik

4. Menjadi pendengar yang baik ketika anak sedang berbicara

5. Mencintai anak dengan cara dia mencintai

Orangtua diminta untuk mengevaluasi sejauh mana mereka sudah berkomunikasi efektif dengan anak-anak mereka. Sebagian besar orangtua mengaku masih belum mengaplikasikannya. Kemudian orangtua diminta memberikan contoh-contoh perilaku yang sudah pernah dilakukan selama ini dan yang akan mereka lakukan di rumah. Contohcontoh perilaku tersebut didiskusikan di dalam kelompok sehingga saling memperoleh masukan sesama anggota kelompok. Kemudian orangtua diminta dengan penuh komitmen untuk mempraktekkan di rumah.

Beberapa hal lain yang terkait dengan pengembangan kemampuan psikosial anak juga didiskusikan pada pertemuan tersebut, antara lain adalah:

1. Mengkomunikasikan cinta dengan katakata penuh kasih sayang, pujian, dorongan yang membesarkan hati, bimbingan, panggilan "sayang" yang baik kepada anak

2. Memberikan hadiah

3. Melayani anak dengan memberikan contoh sampai dia mampu, seperti mengajari anak melayani diri sendiri dan orang lain

4. Bersahabat dan bersenda gurau dengan anak

5. Memberikan sentuhan fisik

6. Memenuhi keinginan anak secara bertahap

Pengembangan psikososial anak perlu dilandasi dengan ajaran agama agar anak mempunyai karakter Islami yang sesuai dengan tuntunan agama. Adapun hal-hal yang dapat dilakukan orangtua adalah:

1. Membangun kejujuran dan membiasakan anak agar menjaga rahasia

2. Membangun kepercayaan sosial melalui pembiasaan membantu orang tua, bergaul dengan teman sebaya, empati
3. Membangun kepercayaan ilmiah dengan mulai dari mengajarkan Al-Qur'an dan Hadits Nabi yang merupakan sumber pengetahuan

4. Membangun jiwa entrepreneur sebagaimana yang dicontohkan oleh Rasulullah.

Contoh-contoh yang dilakukan Rasulullah dalam mendidik anak menjadi suri tauladan juga bagi para orangtua dalam mengembangkan karakter positif pada anak mereka.

Alur pelatihan sesi dua ini lebih banyak dengan diskusi dan memberikan contoh-contoh tindakan langsung yang memungkinkan orantua dapat mempraktekkan di rumah. Tentunya perubahan akan terjadi apabila orangtua melakukan dengan konsisten dan komitmen.

\section{Pelatihan Sesi Ketiga}

Pelatihan Sesi ketiga kami isi dengan materi yang banyak melakukan aplikasi dari materi yang akan disampaikan. Materi yang disampaikan berjudul "Pengembangan Kemampuan Kognitif Anak Usia Dini". Materi ini berisikan tentang pengembangan kognitif anak. Orangtua diajak untuk melihat langsung otak yang distimulasi dengan otak yang diabaikan. Keterlibatan orangtua menjadi salah satu hal penting untuk mengembangkan tumbuh kembang kemampuan anak. Orangtua juga diajarkan untuk bagaimana mengukur kemampuan kognitif anak. Dipaparkan juga aktivitas-aktivitas apa saja yang bisa dilakukan orangtua bersama anak. Setelah memaparkan materi, peserta pelatihan diajak untuk melakukan permainan yang dapat dilakukan bersama anak-anak dirumah. Seperti permainan susun huruf (yang dapat dibuat dari kardus susu), bermain membuat kalimat (oarangtua memasangkan assesoris kepada anak seperti botol minum kemudian anak diminta membuat kalimat dari botol minum), dan permainan kuda bisik (membisikkan satu kalimat kepada teman atau saudara yang lain dan yang terakhir menyebutkan kalimat yang dibisikkan).

\section{Evaluasi}

Setelah melakukan pelatihan, pemateripun membagikan kuisoner yang berisikan tentang materi yang telah peserta dapatkan. Hasil dari kuisoner menunjukkan bahwa (1) $90 \%$ peserta pelatihan merasa bahwa materi yang dibawakan 
pembicara sesuai dengan kebutuhan serta materinya mudah untuk dipahami, (2) $80 \%$ peserta pelatihan berusaha mempraktekkannya dalam mengajar di lembaga PAUD atau mendidik anaknya, (3) $80 \%$ peserta pelatihan menjadi bersemangat menjalani hari-hari sebagai orangtua setelah melakukan kegiatan pelatihan ini.

Sehingga pelatihan ini bermanfaat bagi orangtua untuk meningkatkan kemampuan kognitif dan psikososial anak. Ragam cara yang dapat dilakukan oleh orangtua sambil bermain dengan cara yang menyenangkan. Manfaat lain yang didapatkan orangtua dalam pelatihan itu yaitu orangtua dapat memanfaatkan barang bekas yang ada dirumah untuk bisa dilakukan bersama anak.

Tentunya terdapat kekurangan dalam pelatihan ini seperti waktu penelitian yang terbatas dikarenakan pelatihan ini ditujukan kepada orangtua dimana anak-anaknya harus menunggu orangtuanya dalam mengikuti pelatihan.

\section{KESIMPULAN DAN SARAN}

Pendidikan anak usia dini merupakan salah satu bentuk penyelenggaraan pendidikan yang menitik beratkan pada peletakan dasar ke arah pertumbuhan dan perkembangan fisik (koordinasi motorik halus dan kasar), kecerdasan, daya cipta, kecerdasan emosi, dan kecerdasan spititual. Orangtua-lah yang menjadi pendidik yang pertama dan utama dengan lembaga PAUD sebagai perpanjangan tangan orangtua untuk mencapai tumbuh kembang anak yang optimal.

Menindaklanjuti hasil penelitian terdahulu, sebelum memberikan hal-hal aplikatif yang diajukan oleh orangtua dalam penelitian, peneliti melihat bahwa sebaiknya orangtua terlebih dahlu mengetahui hal-hal dasar dari pertumbuhan dan perkembangan anak secara bertahap. Pada pengabdian masyarakat pada tahap awal ini pengetahuan dasar yang diberikan berupa materi pertumbuhan dan perkembangan anak secara umum yang kemudian dilanjutkan dengan aspek kognitif dan sosial emosi. Oleh karena itu, perlu ada pelatihan lanjutan untuk pemberian materi aspek fisik, seni, dan moral agama.

Pelatihan yang sifatnya aplikatif (keterampilan), baru dapat diberikan setelah peserta memahami pengetahuan dasar tersebut. Pada akhir sesi tersebut nanti, sebaiknya peserta diberikan pertanyaan kembali tentang materi aplikatif yang mereka inginkan agar tepat guna.

\section{DAFTAR PUSTAKA}

[1] Brooks, Jane B. (1991). The Process of Parenting. $\quad 3^{\text {rd }}$ edition. Mayfield Publishing Company

[2] Gredler, Gilbert R.(1992). School Readiness: Assessment and Educational Issues. Clinical Psychology Publishing Company, Brandon, Vermont

[3] Henniger, Michael L. (2013). Teaching Young Children: An Introduction. Pearson

[4] Martin, A. Carole \& Karen K. Colbert. (1997). Parenting : A Life Span Perpective. McGraw-Hill Companies, Inc

[5] Morrison, G.S. (2012). Dasar - Dasar Pendidikan Anak Usia Dini (PAUD). Edisi Kelima (terjemahan). Jakarta: Indeks

[6] Papalia, Diane \& Ruth D Feldman.(2013). Experience Human Development 12ed. McGraw-Hill International Edition

[7] Patmonodewo, Soemiarti. (2000). Pendidikan Anak Prasekolah. Jakarta: Depdikbud \& Rineka Cipta

[8] Semiawan, Conny. 2002. Belajar Dan Pembelajaran Dalam Taraf Usia Dini, Pendidikan Prasekolah Dan Dasar. Jakarta: Prenhalindo.

[9] Wibowo, Timothy. 2012. Rahasia Sukses Pendidikan Karakter: 7 Hari Membentuk Karakter Anak. Jakarta: PT. Grasindo. 